Article

\title{
Economic Inequality and the New School of American Economics
}

\section{Stephen Leccese}

History Department, 613 Dealy Hall, Fordham University, 441 E. Fordham Road, Bronx, NY 10458, USA; Stephen Leccese sleccese@fordham.edu

Academic Editors: Kate Ward and Kenneth Himes

Received: 4 February 2017; Accepted: 10 May 2017; Published: 24 May 2017

\begin{abstract}
This essay analyzes economic inequality in the Gilded Age, roughly from 1865 to 1900. It focuses specifically on a group of economists who identified working-class consumption as an economic stimulus, and accordingly advocated an increase in wages to bring this about. It is structured in three sections: first, it demonstrates how industrialization in the late-nineteenth century sparked social tensions, convincing observers that there was a crisis of inequality; second, it explains how these tensions produced a "New School" of economics who sought to alleviate these issues by changing economic doctrine; it concludes by noting how this New School exerted an influence on public policy in the Progressive Era. In their conception, economics should be redesigned to promote a more equal distribution of wealth. Therefore, higher wages would stimulate working-class consumption, which would stabilize the economy and overall alleviate class conflict. This story offers a unique way to view the development of consumerism and social reform in American history.
\end{abstract}

Keywords: economics; minimum wage; intellectual history; economic reform; Gilded Age; industrialization; consumption

\section{Introduction}

Economic inequality is not a new problem in America, nor are proposed solutions to the problem. Indeed, economic inequality was considered a serious issue in the past, particularly in America's Gilded Age- the period, roughly from the end of the Civil War to the turn of the twentieth century, when a rising wealth gap and conditions among the working class convinced contemporaries that they were facing a crisis of inequality. These conditions sparked a key intellectual change among a group of economists dubbed the "New School." These economists broke from economic traditions, and argued that the discipline of economics should focus on achieving a more equal distribution of wealth for the working class. The New School advanced several theories that altered economics, bu this essay focuses on their views towards wages, poverty, and consumption. Using their published work and archival materials, the essay demonstrates that in response to economic and class unrest in the 1870s and 1880s, the New Economists developed a new political economy focused on the working class. In their theories, consumer spending was the driving force of the modern economy, meaning wages and profits were not at odds with each other. Accordingly, they identified economic inequality as harmful to economic growth and social progress. Increasing the consumer base through wage growth and decreased working hours, these economists argued, would alleviate problems of economic instability and class strife that were associated with America's transition to industrial capitalism.

The New School economists were largely younger Americans who professionally came of age in the tumultuous 1870s and 1880s, when the economy experienced numerous recessions and there seemed to be a threat of open class warfare. Reformer Richard T. Ely described the New School's concerns most succinctly: "We saw a good deal of poverty on the one hand and a concentration of 
wealth on the other hand; and we did not feel that all was well with our country" (Ely 1977, p. 154). Ely and his colleagues considered economic analysis a tool of social reform. One of their many proposed reforms was increasing the consumer base by raising wages and leisure time for the working class. Such a viewpoint, however, put them in conflict with conventional American biases towards wages and consumption. The prevailing view on wages stated that employers could not raise workers' pay without cutting into their own profits. Furthermore, traditional American beliefs regarded thrift as an important moral value; unnecessary spending eroded republican virtue. ${ }^{1}$ Therefore advocating increased spending, as the New School did, endangered the whole republican experiment according to this viewpoint. Such background is necessary to demonstrate the degree to which New School economists were challenging conventional wisdom.

This essay accordingly proceeds in three sections. The first describes how America's rapid industrialization after the Civil War led to social and economic unrest, convincing observers that they were facing a full-fledged crisis of inequality. The second section examines how that crisis of inequality sparked intellectual changes among economists. It notes how the New-School economists developed their ideas and differed from their primary intellectual opponents, the classical liberals. Finally, the essay concludes with a brief examination of how the New School came in contact with politicians and influenced progressive policy at the turn of the century.

\section{The Problem of Inequality}

When twenty-six-year-old Richard T. Ely returned from Europe in 1880, $\mathrm{PhD}$ in economics from the University of Heidelberg in hand, he was deeply disturbed by conditions in his home country. "On my return from Germany, after an absence of three years," he reminisced, "I became aware that our country was experiencing a crisis. The masses desired changes, not merely in surface phenomena, but in the very foundations of the social order" (Ely 1977, p. 66). "The masses" Ely referred to were the millions of wage earners that made up America's working class. Facing poor working and living conditions-explored in detail below-this working class grew increasingly restless, as the number of annual strikes exploded during the 1880s and 1890s. Ely and his colleagues-intellectuals and public servants including Francis A. Walker, John Bates Clark, Edwin Seligman, Henry Carter Adams, Carroll D. Wright, and George Gunton-were of the opinion that an imperfect distribution of wealth was to blame for this social dislocation. They accordingly focused their efforts on analyzing the so-called labor question in America, offering solutions focused on building the domestic market to alleviate economic inequality.

This perception of a crisis of inequality developed along with the Industrial Revolution. Beginning in England in the late eighteenth century, ${ }^{2}$ exponential economic growth became the norm for industrializing countries (Piketty 2014, pp. 1-35). Vastly increased industrial production and availability of affordable consumer goods led several to declare an environment of abundance, in contrast to the preindustrial age of scarcity (Fox 1967, chp. 1). Indeed, during the second half of the nineteenth century, some of the largest fortunes in human history were accumulated among America's "robber barons," the captains of the new mass-production industries that took off after the Civil War. This rapid industrial and economic development allowed the United States to gain world power status in the early twentieth century. ${ }^{3}$

Despite unquestionable progress, however, this was in no way a time of equal wealth distribution. Those who worked for the robber barons often felt as if they were left out of this economic progress. As Thomas Piketty's statistics demonstrate, the Gilded Age saw a sharp increase in wealth inequality, more so than America had experienced in the past. In 1810, the richest $1 \%$ of Americans held about $25 \%$

1 For more on the connections between wealth and virtue, see Dustin Crummett's paper in this volume.

2 For the factors that led to the British Industrial Revolution and the development of its consumer market, see (Allen 2009; McKendrick et al. 1984) .

3 For relative international development, see (Kennedy 1989). 
of the wealth. Between 1870 and 1910, the years of rapid industrialization, that share increased from $31 \%$ to $45 \%$, a jump of nearly 50\% (Piketty 2014, p. 348). As a general trend, real wages increased steadily from 1860 to 1900 as general price deflation decreased the cost of living, a clear benefit to the working class. ${ }^{4}$ Nonetheless, life for working families remained tenuous, mostly characterized by uncertainty. In a world with no welfare or unemployment insurance, job loss or workplace injury could land a family in the streets. Working-class women and children often had to work to supplement a father's income (Dubofsky 1996, pp. 18-30; McGerr 2010, pp. 13-20; Montgomery 1987).

Despite twelve-hour workdays, working class families rarely earned enough to accumulate much of a safety net. As Daniel Horowitz notes, an investigation in 1875 found that working families in Massachusetts spent up to $90 \%$ of their income on basic necessities (Horowitz 1985, chp. 1). With very little savings, lower class families suffered disproportionately in the regular periods of economic depression that struck the country from the 1870s until the turn of the century. When a depression hit, employers most often responded by either cutting wages or laying off workers in mass. (Montgomery 1987, pp. 60-62, 171-72). ${ }^{5}$ Observers of the time saw this situation as the primary social issue of the day. It is no accident that the extremely popular Henry George titled his economic treatise Progress and Poverty, arguing that while "the previous century has been marked by a prodigious increase in wealth-producing power," those who did the productive work toiled in poverty (George 1879, pp. 1-2).

Left with few options, workers increasingly responded to their conditions with strikes. The late nineteenth century saw an explosion in the level of labor unrest: in 1881, when statistics were first kept, there were 477 strikes nationwide; just five years later in 1886 there were 1572; by 1901 there were $3012 .^{6}$ As statistics demonstrate, the majority of these strikes were related to wages and working conditions. Between 1881 and 1900, Historical Statistics of the United States lists three times more strikes due to "wages and working hours" than the next reason, "union organization."7 Some of the largest and most famous strikes of the era were due to direct wage cuts. The Great Railroad Strike of 1877 and the Pullman Strike of 1894, for instance, came in response to multiple reductions to employee wages (Dubofsky 1996, pp. 45-54; Brands 1995, pp. 144-60).

While the working class' material condition was a concern, rising inequality had an equally troubling ideological impact on Americans. The rise of a permanent industrial working class contradicted the national vision that Americans had constructed for themselves. Crucial to that vision was independence and opportunity. Historians have identified a belief that wage labor was meant as a temporary condition for young men while they accumulated enough capital to start their own businesses. This belief was the cornerstone of antebellum free labor ideology (Rodgers 1974). Of course as Eric Foner demonstrates, free labor thought was very much a construction that did not fit reality for American workers. There was always a sizeable wage-laboring class in early America, and historians have noted high levels of poverty, especially in urban areas (Foner 1995, chp. 1; Nash 1986; Stansell 1987). Yet although the ideal did not quite fit the reality, free labor thought remained influential well into the Gilded Age. The labor unrest of the late-nineteenth century, however, demonstrated that free labor ideology had not produced the utopian conditions that Americans expected it to (Foner 1981, chp. 6). The loss of independence that resulted from permanent wage work challenged the vision Americans had crafted for themselves. Of course, as Olivier Zunz demonstrates, well-paid white collar work eventually helped Americans overcome their aversion to permanent wage labor (Zunz 1990, pp. 48-50). However during the transitional period in the Gilded Age, the increasing

\footnotetext{
See Tables 1 and 5 in (Porter 1980).

For a fictional yet revealing account of a working class family's plight, see (Sinclair 1906).

Table Ba4954-4964-Work stoppages, workers involved, average duration, and person-days idle: 1881-1998, HSUS.

Table Ba4965-4970_Work stoppages and workers involved, by major issue: 1881-1981, HSUS. The totals are 13, 919 strikes due to wages and hours, 4291 due to union organization, and 5588 classed as "other".
} 
size of the working class coupled with labor unrest convinced contemporaries that they were facing a legitimate crisis of inequality.

\section{Economic Responses}

Amid instability in economics and social relations, it was plain for all to see that there were problems in American society. Naturally, contemporaries questioned what exactly was wrong. With rigid class formation, America seemed to have developed the very conditions that were supposed to be left behind in Europe, so observers were left scrambling for answers. People of diverse political persuasions and social backgrounds commented on the current state of affairs. There was general consensus that indeed there was a problem - in fact, most industrialized countries of this era struggled with the "social question," namely increasing poverty and class unrest (Fischer 1966). However, the suggested remedies for the problem proved a contentious argument among Americans. Opinions on what exactly had gone wrong had huge implications for the nature of economic inequality and how best to address it.

One response to the economic hard times was reactionary. A collection of economists, businessmen, and editors came to support classical liberalism and traditional economics. Liberal reformers like E.L. Godkin and William Graham Sumner believed that economic and social issues could be solved with a return to the values of classical economics, which they argued had been forgotten during the Civil War. Seeing a large tariff, taxes, and Reconstruction measures, liberals argued that the state needed to go back to its minimal antebellum role. Most importantly, the individual should remain the primary economic actor with no outside interference (Sproat 1968). With such biases, they stuck with the free labor view that low-paid wage labor was only a temporary condition meant for young men. In time, if they were frugal, they would be able to accumulate enough capital to start their own businesses and escape the wage system (Rodgers 1974). By this line of thinking, if one remained a poor wage laborer, then it must be due to some personal shortcoming. Indeed the most common complaints about workers were that they had no self-control and didn't know how to save their money. William Graham Sumner complained that reformers like the New School "gloss over all the faults of the classes in question, and they exaggerate their misfortunes and their virtues." Sumner represents the view that only individuals can pull themselves out of poverty through their own hard work (Sumner 1883, pp. 21-22). If workers lacked the necessary self-restraint, liberals argued, they should be instructed on proper etiquette rather than receive assistance from the state or charity (Sproat 1968, pp. 213-15). Overall, the classical liberals argued that if workers would only learn to save their money, economic problems could be alleviated. ${ }^{8}$

In making their arguments, the liberals were drawing heavily from classical political economy and American traditions. They were students of the English school of political economy and adhered to certain classical tenets like the wage-fund doctrine. Briefly, this doctrine asserts that labor is paid out of a fund built from the last production period. Capitalists take their profits from their previous production and earmark a certain amount to pay as wages in the next period. Wages therefore boiled down to a simple equation: wage-fund divided by number of laborers. ${ }^{9}$ Since the wage-fund came out of a defined pool of capital, economists had traditionally viewed wages and profits as at odds with one another (Smith 2003, p. 94; Ricardo 1817, pp. 144-45; Mill 2001).

In addition to this influence from classical thinkers, liberals also drew from American traditions. Going back to Puritan tradition, thrift and hard work were key values for American society. ${ }^{10}$

8 This is of course not to single out the liberals as evil for their views towards government action. With the rampant government corruption of the Gilded Age, liberals had concrete reasons to mistrust the state. They believed that indeed the best way to alleviate poverty was to stop government interference in the private and economic sphere.

9 John Stuart Mill articulates this doctrine most clearly in (Mill 2001) For a more concise definition see (Cohen 2002; Currarino 2011).

10 The classic analysis on work ethic remains (Weber 1930). 
Accordingly, antebellum Americans held decidedly ambivalent views towards consumption and placed far greater value on productivity. This focus on thrift was not simply because Americans liked saving money; thrift was intimately tied to republican virtue. Americans decried consumption and luxury as harmful and even immoral. The bias among Americans was that European society had become corrupt through luxury. Attempting to avoid the problems of Europe, Americans placed a high value on republicanism, of which a large part was an independent, virtuous citizenry. ${ }^{11}$ Luxury spending was thought to erode this individual virtue. By this logic, consumption and luxury endangered America's entire republican experiment (McCoy 1980). Popular writers like Amasa Walker wrote about the moral character of consumption. He distinguishes between money "spent" on luxuries and money "reproduced" when it is invested as capital. For Walker, "right consumption" was only useful insofar as it encouraged industry from a person, which is a key republican trait (Walker 1867). In sum, thrift meant much more for Americans than simple economic principles-it helped form the basis of the republican society they were trying to create.

While the liberals took their influence from these traditional ideals, the New School's inspiration came from what they considered a more modern source, the German Historical School. Throughout the 1870 s and 1880s, Germany responded to the social problems of industrialization by building a proto-welfare state. Historical economists supported such measures through organizations like the Verein für Sozialpolitik (Association for Social Policy), which produced qualitative studies of social problems and recommended corrective legislation. (Grimmer-Solem 2003; Rodgers 1998; Schäfer 2000). A prevailing intellectual trend of the day was exchange between Germany and the United States, as American students travelled there and studied with key figures of the Historical School. With ideas from Germany, many of these students came back to the United States and became primary actors in the budding Progressive Movement (Rodgers 1998; Schäfer 2000).

With influence from Germany, the New School began developing new ideas about the economy and society. At the core of their creed was a rejection of the liberal view that society was merely a collection of individuals. Rather, as Richard Ely articulated, society was its own organism that had different needs than its individual parts (Ely 1889, p. 14). Since society was an organism, poverty among one class inhibited the development of the whole social body. Using this logic, the New School rejected the belief that wages and profits were at odds. Alleviating poverty and economic inequality would serve as an economic stimulus, as the working class could therefore have more disposable income. With better economic conditions, workers would have no reason to strike, leading to a peaceful and prosperous society.

The first American to address these issues was Francis A. Walker. Walker did not study abroad, but his work as a government statistician led him to similar conclusions that society was a complex organism (Dorfman 1949, pp. 101-3). Rather than despair over the shocking development of a permanent industrial working class, Walker made that working class an object of economic analysis in his 1876 work, The Wages Question. Seeing struggling laborers led Walker to conclude that mere subsistence wages are not efficient and lead to the degradation of labor. Poor food and housing will cause a decline in health, making workers unable to work as productively. Going further, Walker argues that consistent poverty destroys peoples' ambition. Therefore the threat of starvation is not a motivator, but a cause of overall moral and economic degradation (Walker 1876, pp. 84-88).

With this framework, Walker then moved on to attack the prevailing view on wages, the wage-fund doctrine. He found the wage-fund doctrine static and unrealistic. Employers do not consciously build a fund that they plan to dispense in the form of wages, he argued; rather, wages represent a purchase of labor power. Capitalists purchase labor as an investment to produce wealth. Therefore wages represent an advance payment, as the capitalist hopes to profit from his production

11 For the various understandings of the qualities of republicanism and its importance in early America, see (Wood 1969; Shalhope 1982). 
(Walker 1876, pp. 109-10; Walker 1875, pp. 102-3). By this new understanding, wages shouldn't be considered a static price that cannot rise, but rather something that should increase in value as the wealth produced rises.

Walker's penchant for challenging orthodoxy earned him a prestigious place among the emerging New School. The group advanced from a loose network of economists dissatisfied with the status quo to an organized force with the foundation of the American Economic Association in 1885, with Walker elected as its first president. ${ }^{12}$ The group's primary architect, Richard Ely, deliberately modeled the group on the German Verein für Sozialpolitik, and all founding officers except Walker-Ely, John Bates Clark, Edwin Seligman, Edmund James, and Henry C. Adams-had studied in Germany. ${ }^{13}$ There were many facets in the new theories that the New School advocated, but for the topic of economic inequality, it is most effective to analyze how the New School developed a new theory of wages to address poverty. For the New School, a primary economic issue was that mass production had become so efficient that goods were manufactured faster than they could be consumed. In America, the so-called under-consumption thesis can be traced back to the 1860s, when Commissioner of the Revenue David Wells noted that industrial production was outrunning population growth. ${ }^{14}$ The idea that under-consumption was the cause of hard times grew from there. Labor leaders connected high wages to increased consumption from at least the early 1860s. Most notably Ira Steward of the eight-hour movement argued that working-class consumption would prove beneficial to the economy (Douglas 1932; Glickman 1997). ${ }^{15}$ This opinion penetrated academic economics during the 1870s and 1880s. In what could be dubbed "the discovery of the consumer," the New School argued that problems of economic instability and inequality could be solved with a vastly expanded consumer base. Some contemporaries thought the need for consumers meant the US should expand overseas in search of markets. The New School argued that these new markets were available domestically, in the form of America's large working class. Rather than the liberals, who argued that workers needed to be taught self-control, these rebellious economists were of the opinion that the working class should be given the resources to consume more. ${ }^{16}$

To advance this theory, the New School had to break the notion that wages and profits were at odds with each other. Walker had already made strides against the wage-fund doctrine, but he still considered thrift an important individual virtue (Walker 1883, p. 73). Others pushed the argument further and argued that high wages and consumption were in fact good for business and economic prosperity. There are numerous intellectuals who fit into this mold. However for concise yet revealing examples, we can look to economists John Bates Clark and George Gunton. They both specifically use the well-being of the working class as their main object of analysis, making them a perfect fit for the theme of addressing economic inequality. Moderately influenced by socialist economics, Clark and Gunton overall argue that a poor working class was counterproductive for social stability and economic growth. It represented an untapped consumer market that if given the resources, would boost domestic consumption significantly.

John Bates Clark recognized that mass production had made an enlarged consumer base an economic necessity, and argued that the best way to achieve this was to ensure that "workers share in the benefits of civilization" (Clark to Seligman 1891). In attacking the wage-fund, Clark shows his socialist influence in pointing out that labor produces the wealth for the capitalist. Therefore, wages do not consist of a fund built by the capitalist and earmarked for wage payments, as the wage-fund dictates. Rather, wages represent labor's fair share in the production of wealth (Clark 1887, pp. 126-30).

\footnotetext{
2 For background on the formation of the AEA, see (Furner 1975).

(Ely to Seligman 1885; American Economic Association 1886).

(New York Times 1869; Wells 1877).

Steward did not produce much writing in his lifetime, but for his views see (Steward 1863; Steward 1868)

For an explanation of how these issues of consumption were tied to economic citizenship, see (Currarino 2011).
} 
Low wages do not represent a fair share of production because labor is therefore owed far more than it receives.

But Clark went further than simply demonstrating the injustice of low wages-he argued that raising the working class' condition was an economic stimulus. Paying workers as little as possible and allowing them no leisure time was an attempt to transform them into productive machines. Clark argues that this expectation hurts capitalists, ultimately, because "to make a man a machine is to make him anything but productive" (Clark 1887, p. 53). On the other hand, if workers are provided with leisure time and more spending power, they will use the opportunity for rest and relaxation. Not only will the increased consumption stimulate the economy, but capitalists will benefit from labor force that is more productive because it has restored its energy.

George Gunton even more forcefully argued that high wages were a benefit for everyone, expanding his analysis to envisioning a society centered on consumption. As a student of Ira Steward, Gunton pushed the theory of consumption to its logical end, essentially arguing that a consumerist society was the only way to achieve social stability. Gunton identified poverty as overall harmful to society, and argued that "social progress depended upon improving the material condition of the masses" (Gunton 1887, p. 23, 78). However, Gunton didn't advocate an abolition of capitalism to end inequality, as other radicals did. Instead he advocated a form of wealth redistribution that involved increasing the overall wealth of society. A way to bring this about was through an increase in consumption. In his view, the working class is so numerous that even a small increase in consumption would mean huge economic growth (Gunton 1891, p. 85). His theory essentially argued that all boats could rise equally in this new economic environment of abundance.

Key to Gunton's work was of course increasing wages. Gunton attacked the belief that high wages hurt profits. That line of thinking assumes that workers are only producers and not consumers as well. But as Gunton wrote, "consumption is the economic basis of production," and "the laborer is as important factor in the one as he is in the other" (Gunton 1887, pp. 30-31). Therefore, low wages only result in a limited market because the working class can only consume necessities. Ultimately, this hurts the capitalists, because it eliminates the consumer base and prevents the expansion of markets. Gunton argued that wages did not represent a cost, but an investment. Higher wages were a temporary expense that would provide capitalists with an expanded market for their goods. This investment would eventually return to them in the form of profits (Gunton 1887, p. 7).

According to the views of Clark, Gunton, and others, poverty and low wages were a social and economic handicap. They would not deny that there was significant economic growth in the late-nineteenth century-statistics make this clear, and the New School expressed wonder at the human progress that had produced such growth. Yet it was a "nervous prosperity," to use historian Albro Martin's phrase. For observers of the time, this growth seemed uneven, with serious depressions in 1873,1882 , and 1893, in addition to smaller panics. ${ }^{17}$ Their argument was that long-term stability required a more even distribution of wealth. Such a measure would prevent depressions and improve the working class' standard of living, thereby resulting in a more peaceful society free of class strife.

\section{The New School and Public Policy}

Yet fascinating as this intellectual story is, the New School's efforts would mean little if they did not exert real-world influence. As history shows, indeed they did. The New School did not merely theorize about alleviating economic inequality. They also took active steps to influence public policy, and exercised an understated influence on progressive reform at the turn of the twentieth century.

As labor unrest intensified, the federal government realized the situation required closer study, rather than just usage of federal troops to crush strikes. A key figure in the development of state policy was New School member Carroll D. Wright. As a pioneer in the collection and assessment

17 See (Martin 1980). 
of labor statistics in Massachusetts - it was his report in 1875 that uncovered the condition of that state's working families - he was the obvious choice to head the new federal Bureau of Labor Statistics, formed in 1884. His first report as Commissioner of Labor echoes the under-consumption thesis that his New-School colleagues subscribed to. Wright identifies the twin problems of overproduction and under-consumption as the cause of the general boom and bust cycle of the late 1800s. While writing that there is "no absolute remedy for depressions," Wright nonetheless makes suggestions that could alleviate the intensity and length of economic panics. Among his recommendations are increasing the purchasing power of laborers through the introduction of a stable currency, control of the labor supply by limiting contract labor, and a shortening of the work day. Wright theorized that such methods would increase the consuming power of the general public. This would enable the domestic market to absorb excess production (Wright 1968, pp. 290-93). Wright served as Commissioner of Labor for twenty years until 1905, and continued advocating his version of the under-consumption thesis (Leiby 1960, p. 136).

Wright was of course Commissioner of Labor when Theodore Roosevelt was making his name as the first progressive president, and Roosevelt considered him an important adviser. Wright was especially an influence on Roosevelt's decisions in arbitrating the 1902 Anthracite Coal Strike. ${ }^{18}$ Roosevelt, however, was already well-acquainted with the New School by the time he became president. Several economists served as Roosevelt's advisers or confidantes when he was governor of New York from 1899 to 1900. At various points, George Gunton, Edwin Seligman, Richard Ely, and John Bates Clark advised Roosevelt on policy related to economics, labor, and big business (Chessman 1965; Hurwitz 1968). ${ }^{19}$

We can see the New School's influence in certain legislation that Roosevelt supported and passed. For instance, George Gunton was once asked in a lecture what legislation he would pass if given the opportunity, and he outlined three laws: First, a universal eight-hour law; second, a pension program to assure workers an income after retirement; and third, that children under 16 would not be permitted to work more than half-time. Gunton's reasoning was that protections like these would increase leisure time for workers to spend money, supporting his theory for a consumer society (Gunton 1897). Upon becoming governor, Roosevelt named Gunton his labor adviser and passed similar legislation, including an eight-hour law for public employees, regulation of child labor, and minimum wage increases for certain public and private sector employees (Hurwitz 1968, pp. 220-28). Such actions stand as an example that the New School was not satisfied with simply theorizing about social reform, but took active steps to influence policy. In Roosevelt, they found a political partner who was open to their suggestions on certain progressive legislation, particularly labor protections. Roosevelt incorporated their ideas into his platform as one of the most important policymakers of the Progressive Era.

\section{Conclusions}

While the previous investigation is far from comprehensive, it demonstrates clearly that economists of the New School identified economic inequality as harmful to social progress in Gilded-Age America. From their viewpoint, they saw class unrest and economic instability all around them, leading to fears that society was on the verge of revolution. The New School blamed shortcomings in classical economics for this condition, due to a focus on production and the capitalist middle class over the working class. In shifting their focus from production to distribution, the New School developed theories on how to ensure the working class benefitted from industrialization. To solve the problem, they advocated a greater level of wage equality to stimulate working-class

18 See examples of Wright and Roosevelt's correspondence in Letters of Theodore Roosevelt (Morrision 1951-54a).

19 For instances where Roosevelt sought their advice and input, see TR Letters (Morrision 1951-54b, 1129, 1239). 
consumption. This principle-increasing mass consumption-became key to adjusting economics to fit modern conditions, as the New School saw it.

In making these arguments, the New School offers a unique framework from which to view mass consumption. Historians often view consumerism as a development driven by business elites, who used advertising techniques to shape the American public into consumers (Ewen 1976; Leach 1994; McGovern 2009; Scanlon 1995). Yet as we've seen, advocates of consumerism were not always businessmen hoping to maximize profit. The New School economists conceived of consumption as a tool of social reform. They believed that by transforming the working class into consumers, America could achieve economic and social stability. We can further see how these theories were put into practice, as Theodore Roosevelt's New School advisers advocated protections for the working class through eight-hour laws and minimum wages. Exploring the New School therefore provides an enlightening, if unconventional, way to view social reform and how problems of economic inequality were addressed in the past.

Conflicts of Interest: The author declares no conflict of interest.

\section{References}

Allen, Robert C. 2009. The British Industrial Revolution in Global Perspective. New York: Cambridge University Press. American Economic Association. 1886. List of Officers and Members. Publications of the American Economic Association 1: 40-46.

Brands, H.W. 1995. The Reckless Decade: America in the 1890s. New York: St. Martin's Press.

Chessman, Wallace G. 1965. Governor Theodore Roosevelt: The Albany Apprenticeship, 1898-1900. Cambridge: Harvard University Press.

Clark, John Bates. 1887. The Philosophy of Wealth: Economic Principles Newly Formulated, 2nd ed. Boston: Ginn.

John Bates Clark to Edwin Seligman, 30 May 1891, Folder 8, Box 1, Series 1: Correspondence, John Bates Clark Papers, Columbia University Rare Book and Manuscript Library, New York, NY.

Cohen, Nancy. 2002. The Reconstruction of American Liberalism, 1865-1914. Chapel Hill: University of North Carolina Press.

Currarino, Rosanne. 2011. The Labor Question in America: Economic Democracy in the Gilded Age. Urbana: University of Illinois Press.

Dorfman, Joseph. 1949. The Economic Mind in American Civilization Vol. 3: 1865-1918. New York: Viking Press.

Douglas, Dorothy. 1932. Ira Steward on Consumption and Unemployment. Journal of Political Economy 40: $532-43$. [CrossRef]

Dubofsky, Melvyn. 1996. Industrialism and the American Worker, 1865-1920, 3rd ed. Wheeling: Harlan Davidson.

Ely, Richard T. 1889. An Introduction to Political Economy. New York: Chautauqua Press.

Ely, Richard T. 1977. Ground under Our Feet: An Autobiography. New York: Arno Press.

Richard T. Ely to Edwin Seligman, 23 June 1885, Box C9, Series 1: Correspondence, Edwin R.A. Seligman Papers, Columbia University Rare Book and Manuscript Library, New York, NY.

Ewen, Stuart. 1976. Captains of Consciousness: Advertising and the Social Roots of the Consumer Culture. New York: McGraw-Hill.

Fischer, Wolfram. 1966. Social Tensions at Early Stages of Industrialization. Comparative Studies in Society and History 9: 64-83. [CrossRef]

Foner, Eric. 1981. Politics and Ideology in the Age of the Civil War. New York: Oxford University Press.

Foner, Eric. 1995. Free Soil, Free Labor, Free Men: The Ideology of the Republican Party before the Civil War, 2 nd ed. New York: Oxford University Press.

Furner, Mary O. 1975. Advocacy and Objectivity: A Crisis in the Professionalization of American Social Science, 1865-1905. Lexington: University Press of Kentucky.

Fox, Daniel M. 1967. The Discovery of Abundance: Simon N. Patten and the Transformation of Social Theory. Ann Arbor: University of Michigan Press.

George, Henry. 1879. Progress and Poverty. New York: Doubleday, Page and Co.

Glickman, Lawrence. 1997. Workers of the World, Consume: Ira Steward and the Origins of Labor Consumerism. International Labor and Working-Class History 52: 72-86. [CrossRef] 
Grimmer-Solem, Erik. 2003. The Rise of Historical Economics and Social Reform in Germany, 1864-1894. New York: Clarendon Press.

Gunton, George. 1887. Wealth and Progress. New York: D. Appleton.

Gunton, George. 1891. Principles of Social Economics. New York: G.P. Putnam's Sons.

Gunton, George. 1897. “Our Economic Creed," Lecture Bulletin of the Institute of Social Economics.

Horowitz, Daniel. 1985. The Morality of Spending: Attitudes toward the Consumer Society in America, 1875-1940. Baltimore: Johns Hopkins University Press.

Hurwitz, Howard. 1968. Theodore Roosevelt and Labor in New York State, 1880-1900, 2nd ed. New York: AMS Press.

Kennedy, Paul. 1989. The Rise and Fall of the Great Powers. New York: Vintage.

Leach, William. 1994. Land of Desire: Merchants, Power, and the Rise of a New American Culture. New York: Vintage.

Leiby, James. 1960. Carroll Wright and Labor Reform: The Origin of Labor Statistics. Cambridge: Harvard University Press.

Martin, Albro. 1980. Economy from Reconstruction to 1914. Boston: Division of Research, Graduate School of Business Administration, Harvard University.

McCoy, Drew R. 1980. The Elusive Republic: Political Economy in Jeffersonian America. Chapel Hill: University of North Carolina Press.

McGerr, Michael. 2010. A Fierce Discontent: The Rise and Fall of the Progressive Movement in America. 1870-1920. New York: Free Press.

McGovern, Charles. 2009. Sold American: Consumption and Citizenship, 1890-1945. Chapel Hill: University of North Carolina Press.

McKendrick, Neil, John Brewer, and J.H. Plumb. 1984. The Birth of a Consumer Society: Commercialization of Eighteenth Century England. London: HarperCollins Publishers Ltd.

Mill, John Stuart. 2001. Principles of Political Economy. Kitchener: Batoche Books.

Montgomery, David. 1987. The Fall of the House of Labor: The Workplace, the State, and American Labor Activism, 1865-1925. New York: Cambridge University Press.

Elting Morrision, ed. 1951-54a. Letters of Theodore Roosevelt. Cambridge: Harvard University Press, vol. 1.

Elting Morrision, ed. 1951-54b. Letters of Theodore Roosevelt. Cambridge: Harvard University Press, vol. 2.

Nash, Gary B. 1986. The Urban Crucible: The Northern Seaports and the Origins of the American Revolution. Cambridge: Harvard University Press.

New York Times. 1869. Third Annual Report of Commissioner David A. Wells. New York Times, January 6.

Piketty, Thomas. 2014. Capital in the Twenty-First Century. Translated by Arthur Goldhammer. Cambridge: Belknap Press.

Porter, Glenn. 1980. Prices and Wages. In Encyclopedia of American Economic History. New York: Simon \& Schuster Trade, pp. 234-44.

Ricardo, David. 1817. On the Principles of Political Economy and Taxation. London: J. M'Creery.

Rodgers, Daniel T. 1974. The Work Ethic in Industrial America 1850-1920. Chicago: University of Chicago Press.

Rodgers, Daniel T. 1998. Atlantic Crossings: Social Politics in a Progressive Age. Cambridge: Belknap Press.

Scanlon, Jennifer. 1995. Inarticulate Longings: The Ladies' Home Journal, Gender, and the Promises of Consumer Culture. New York: Routledge.

Schäfer, Axel R. 2000. American Progressives and German Social Reform, 1875-1920: Social Ethics, Moral Control, and the Regulatory State in a Transatlantic Context. Stuttgart: Franz Steiner Verlag.

Shalhope, Robert E. 1982. Republicanism and Early American Historiography. William and Mary Quarterly 39: 333-56. [CrossRef]

Sinclair, Upton. 1906. The Jungle. New York: Doubleday.

Smith, Adam. 2003. The Wealth of Nations. New York: Random House.

Sproat, John G. 1968. "The Best Men": Liberal Reformers in the Gilded Age. New York: Oxford University Press.

Stansell, Christine. 1987. City of Women: Sex and Class in New York, 1789-1860. Urbana: University of Illinois Press.

Steward, Ira. 1863. The Eight Hour Movement: A Reduction of Hours is an Increase of Wages. Boston: Boston Labor Reform Association.

Steward, Ira. 1868. The Meaning of the Eight Hour Movement. Boston: self-published.

Sumner, William Graham. 1883. What Social Classes Owe To Each Other. New York: Harper \& Brothers.

Walker, Amasa. 1867. The Science of Wealth. Boston: Little Brown and company.

Walker, Francis Amasa. 1875. The Wage-Fund Theory. North American Review 120: 84-119. 
Walker, Francis A. 1876. The Wages Question. New York: Henry Holt.

Walker, Francis A. 1883. Political Economy. New York: Henry Holt.

Wells, David Ames. 1877. How Shall the Nation Regain Prosperity? North American Review 125: 110-32.

Weber, Max. 1930. The Protestant Ethic and the Spirit of Capitalism. Translated by Talcott Parsons. New York: Scribner.

Wood, Gordon S. 1969. The Creation of the American Republic, 1776-1787. Chapel Hill: University of North Carolina Press.

Wright, Carroll D. 1968. Industrial Depressions: The First Annual Report of the United States Commissioner of Labor. New York: Augustus M. Kelly Publishers.

Zunz, Olivier. 1990. Making America Corporate, 1870-1920. Chicago: University of Chicago Press.

2017 by the author. Licensee MDPI, Basel, Switzerland. This article is an open access article distributed under the terms and conditions of the Creative Commons Attribution (CC BY) license (http:/ / creativecommons.org/licenses/by/4.0/). 